\title{
Novel role for lysophosphatidic acid in vascular remodeling at the maternal-fetal interface
}

\author{
Jimena S Beltrame, Vanesa A Cañumil, Micaela S Sordelli and María L Ribeiro \\ Laboratory of Physiology and Pharmacology of Reproduction, Center of Pharmacological and Botanical Studies \\ (CEFYBO), CONICET - University of Buenos Aires, Buenos Aires, Argentina
}

Correspondence should be addressed to / S Beltrame; Email: jimenabeltrame@gmail.com

\begin{abstract}
Lysophosphatidic acid (LPA) belongs to the group of phosphorylated lipids reported as crucial mediators in the physiology of reproduction. LPA binds to G-protein-coupled receptors and regulates a wide range of female reproductive functions. This bioactive lipid has also been implicated in vascular functions during physiological and pathological conditions. In this regard, the establishment of a successful pregnancy requires proper coordination of vascular processes and remodeling of maternal blood vessels during early gestation. During this process, first trimester cytotrophoblast changes from an invasive to an endovascular phenotype and transforms uterine spiral arteries which are the nutrient supply for placenta and fetus. Here we present an overview of LPA participation in vascular remodeling and highlight the importance of LPA-LPA3 signaling during early gestation at the maternal-fetal interface. Reproduction (2020) 159 R55-R67
\end{abstract}

\section{Implantation, decidualization and placentation}

Embryo implantation into the maternal uterus comprises highly coordinated events and is a crucial step for the establishment of a healthy pregnancy in mammals (Wang \& Dey 2006, Cha et al. 2012).

In humans, implantation begins with the apposition of the blastocyst until the extravillous cytotrophoblast invades the maternal endometrium. The blastocyst could implant only during the window of implantation which lasts for a limited period of time after ovulation. At this transient and unique moment, the active embryo interacts with the receptive endometrium, which supports embryo growth, attachment and the following stages of implantation (Zhang et al. 2013). In mice, the uterus is fully receptive approximately $72 \mathrm{~h}$ after ovulation. However, in humans, uterine receptivity occurs between 7 and 10 days after ovulation.

The process of implantation is extremely complex and could be classified into three stages: apposition, adhesion, and invasion (Fig. 1) (Hertig et al. 1956, Lindenberg 1991). Once the blastocyst apposes on the uterine epithelium, the outer layer of the blastocyst, the trophectoderm, increases the physical contact and establishes a strong and stable adhesion to the endometrium. During the invasion, the trophectoderm penetrates between the luminal epithelial cells to the basal lamina and extends to the uterine stroma, therefore establishing a stable maternal-fetal interface (Pijnenborg et al. 1980).

Embryo implantation promotes extensive modifications of the uterine stroma. The endometrial fibroblasts rapidly grow and differentiate into decidual cells. Decidualization is a crucial event in early pregnancy and is fundamental for the success of gestation in humans and mice (Dey \& Lim 2006). In mice, the presence of an active blastocyst in the uterus is the stimulus for the decidual reaction. After attachment on day 4 of pregnancy, stromal cells surrounding the implanting blastocyst begin to proliferate extensively and differentiate (Tan et al. 2002). In women, predecidualization around the terminal spiral arteries of the superficial endometrial layer is under maternal control and occurs in the mid-luteal phase of the cycle in response to increasing levels of progesterone and cAMP (Wilcox et al. 1999). In the case of pregnancy, there is an extensive and profound burst in the decidual reaction. The decidua controls trophoblast invasion, regulates the activation of the immune system and protects and nourishes the growing embryo until the placenta is completely formed and functional.

Besides decidualization, a successful pregnancy includes the development of neovasculature, spiral arteries remodeling, and subsequent placentation. The placenta, a unique organ in mammals, reassures that the blood flow and nutrients exchange are sufficient during the whole gestation. During human placental development, the trophoblast differentiates to comprise pivotal mechanisms that allow fetal and maternal adaptations to pregnancy (Liu et al. 2018, Vento-Tormo et al. 2018). The villi are the functional units of the placenta and consist of an outer epithelial trophoblast layer and a stromal cell core. The mature human 


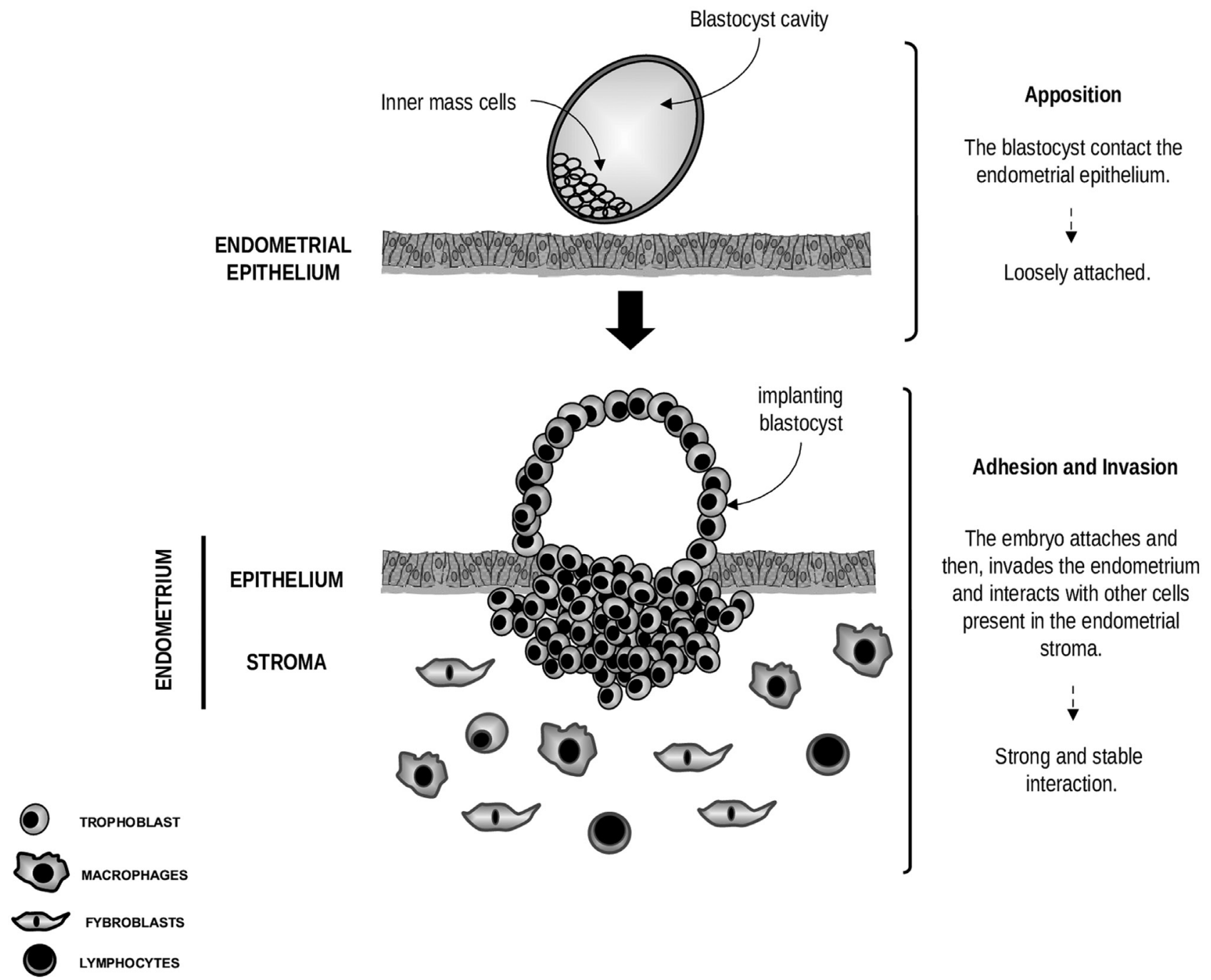

Figure 1 Stages of implantation. During implantation, the embryo apposes and adheres to the luminal endometrium before invasion begins.

placenta has three major types of epithelial trophoblast: the syncytiotrophoblast, the villous cytotrophoblast and the extravillous cytotrophoblast (Maltepe \& Fisher 2015). The villous cytotrophoblast form a single layer that lines the stromal cell core and are the source of the replenishment of the syncytiotrophoblast and the extravillous trophoblast. Villous cytotrophoblast cells fuse and form the multinucleated syncytiotrophoblast which has mainly secretory functions and exerts an active role in the nutrition and gas exchange with the developing embryo. In the extravillous pathway, villous cytotrophoblast cells differentiate into interstitial extravillous trophoblast or endovascular extravillous trophoblast. In humans, the initial wave of invasion occurs via the formation of a primitive syncytium through which the cytotrophoblast escapes from the villi and acquire an invasive phenotype (Da SilvaArnold et al. 2015). Invasive extravillous trophoblast is derived from column cytotrophoblast progenitors located at the tips of anchoring villi, migrates through the uterine parenchyma, and invades the decidua until the third portion of the myometrium. On the other hand, the endovascular extravillous trophoblast remodels the maternal vasculature (Zhou et al. 1997a, Kam et al. 1999). The main goal of cytotrophoblast invasion is to reach the uterine spiral arteries and remodel the preexisting vessels, to increase blood flow and subsequent supply of nutrients and oxygen to the growing embryo (Zhou et al. 1997a,b).

When apposition, adhesion or invasion do not take place or are incomplete, the embryo fails to implant. Each step depends on the success of the preceding event. Early pregnancy loss is a worldwide concern and often occurs due to defects before, during or immediately after implantation (Wilcox et al. 1988, Zinaman et al. 1996). Despite advances in human reproductive technology, pregnancy rate remains low related to implantation failure (Cha et al. 2012, Miller et al. 2012, Patrizio \& 
Silber 2017). Therefore, understanding the implantation mechanism is a challenge to alleviate early pregnancy loss and infertility problems.

\section{Vascular remodeling at the maternal-fetal interface}

Vascular remodeling is a key mechanism triggered after invasion and lacunae formation. Uterine blood supply consists of multiple branches that decreases in diameter while invading the endometrium and myometrium. During pregnancy, the vascular bed of the uterus changes dramatically, where new vessels are formed and the existing vessels dilate. Particularly, blood flow increases and vascular resistance decreases as a result of a highly coordinated process known as spiral artery remodeling. In this sense, coiled appearance vessels named spiral arteries are transformed from strained and rigid muscular walls arteries into flaccid sinusoidal sacs that allow a significant increase in blood flow to sustain normal growth (Fig. 2) (Harris et al. 2006, Leach et al. 2006, Demir et al. 2010).

Coordination of vascular processes at the maternalfetal interface is essential for maintenance of gestation and requires a deep reorganization of uterine and fetal tissues. Several mechanisms are proposed for spiral artery remodeling including cellular migration, apoptosis, inhibition of proliferation and endovascular differentiation (Cartwright et al. 2010, Cartwright \& Whitley 2017). Although the precise pathways are not fully elucidated, it is accepted that spiral artery remodeling involves an active role of the extravillous cytotrophoblast.

Throughout placentation, human extravillous cytotrophoblast begins an active differentiation while migrates, invades decidual stroma and surrounds the spiral arteries. Afterward, the extravillous cytotrophoblast penetrates into the vascular lumen and replaces the endothelial cells of these vessels. This 'remodeling of spiral arteries' or 'trophoblast angiogenesis' involves a switch in cytotrophoblast phenotype and function from an invading to an endovascular one (Kam et al. 1999, Benirschke \& Kaufmann 2000, Espinoza et al. 2006, Pijnenborg et al. 2006). Endovascular trophoblast mimics endothelial cells profile of blood vessels changing the expression pattern of adhesion molecules allowing interaction with different cell types (Burrows et al. 1994). Initially, cytotrophoblast expresses epithelial type adhesion molecules such as integrin $\alpha 6 / \beta 4$ and $\alpha 6 / \beta 1$ and E-cadherin. During the differentiation from cytotrophoblast to endovascular cytotrophoblast it begins to express integrins $\alpha 1 / \beta 1$ and $\alpha 5 / \beta 3$, as well as VE-cadherin, PECAM- 1 and VCAM1 , classically expressed by the endothelium that it will replace. In particular, Zhou et al. (1997a) observed that E-cadherin expression by trophoblast inhibits invasion affecting vascular remodeling. It is worth mentioning that in preeclampsia, cytotrophoblast does not express

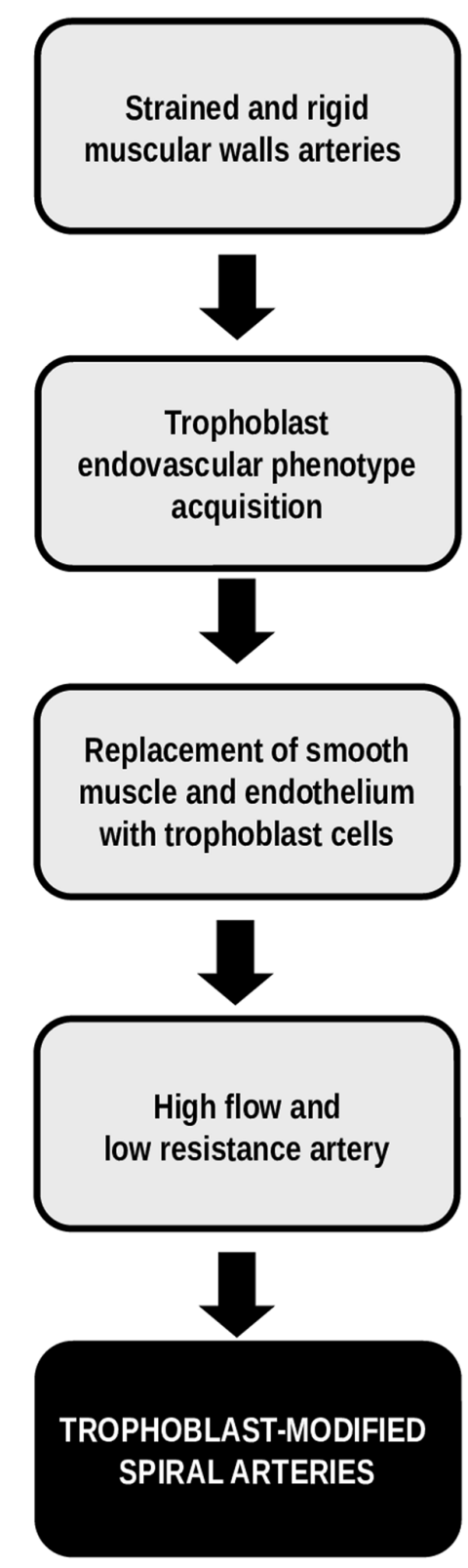

Figure 2 Spiral artery remodeling. Proposed mechanisms involved in the transformation of the uterine spiral arteries from strained and rigid vessels into flaccid sinusoidal sacs.

endothelial markers, suggesting a failure in changing the trophoblast profile necessary for vascular remodeling (Zhou et al. 1997b, McMaster et al. 2004).

In addition to endovascular cytotrophoblast phenotype, spiral arteries transformation implicates loss or re-arrangement of smooth muscle layers and endothelial cells of maternal vessels, comprising the activation and vacuolization of endothelial cells as well as disorganization of smooth muscle cells (Cartwright et al. 2010). One question to be addressed is what directs trophoblast cells toward maternal spiral arteries. It is proposed that endovascular trophoblast 
interacts directly with endothelial cells, while interstitial trophoblast interacts with smooth muscle cells (Cartwright \& Whitley 2017). Particularly, the presence of endovascular cytotrophoblast was detected in spiral arteries after 8 weeks of gestation and is more prevalent at 10 weeks (Pijnenborg et al. 1980). This reorganization is accomplished when the endovascular trophoblast is surrounded by fibrin deposits giving structure to the remodeled vessel. As result of this mechanism, approximately 150 human spiral arteries acquire greater caliber and blood flow with low resistance, shifting the average luminal size from $200 \mu \mathrm{m}$ to $2 \mathrm{~mm}$ (Boyd \& Hamilton 1970, Benirschke \& Kaufmann 2000, Lyall 2005). The importance of these events occurring in a regulated manner is evidenced by obstetric pathologies associated with insufficient spiral arteries remodeling during early pregnancy (implantation failures and recurrent miscarriage) and late pregnancy (preeclampsia and intrauterine growth retardation) (Khong et al. 1986). Understanding the potential causes of the disorders related to inadequate vascular remodeling would help to design new approaches to alleviate these pathologies.

\section{General characteristics of LPA}

LPA is the simplest natural lysophospholipid yet discovered with one fatty acid chain, a glycerol backbone with a hydroxyl group and a phosphate group as a polar head (Fig. 3) (Tokumura 1995, Moolenaar 1999, Tigyi \& Parrill 2003). For many years, scientists thought that LPA was only an intermediate in de novo lipid synthesis and a component of plasma membranes. However, LPA is a family of structurally related compounds composed by saturated fatty acids (16:0, 18:0) and unsaturated fatty acids (16:1, 18:1, 18:2, 18:3, 20:4) which show differential biological activities by activating different receptors in human and rat (Tokumura et al. 1986, Gerrard \& Robinson 1989, Eichholtz et al. 1993, Baker et al. 2000, Sano et al. 2002, Sugiura et al. 2002). In biological fluids, LPA is generally bound to chaperones

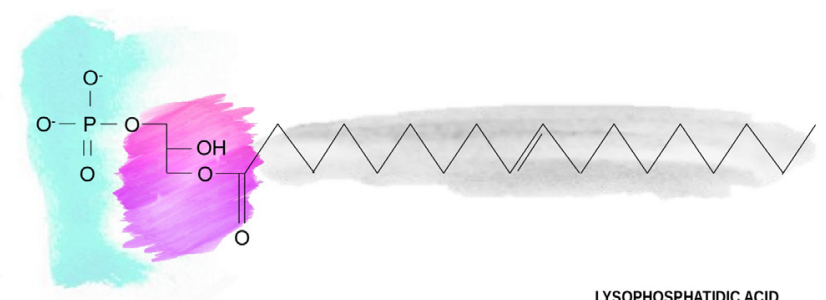

PHOSPHATE GROUP

GLYCEROL BACKBONE

FATTY ACIL CHAINS

Figure 3 Molecular structure of LPA. LPA is formed by one fatty acid chain, a glycerol backbone with a hydroxyl group and a phosphate group.
(Mills \& Moolenaar 2003, Blaho \& Chun 2018). In plasma, $16: 0$ is the predominant species, while 18:0, 18:1, 18:2, 18:3 and 20:4 forms are present at lower concentrations (Akira et al. 1986, Choi et al. 2010).

So far, it has been reported that activated platelets produce high concentrations of LPA in the organism (Eichholtz et al. 1993, Leblanc et al. 2018). However, these are not the exclusive source of this bioactive lysophospholipid. Although LPA is produced after platelet activation, the amount of LPA released is insufficient to explain its levels in serum. The concentration of LPA in serum increases more than ten-fold compared to plasma (1 vs $0.1 \mu \mathrm{M})$ (Eichholtz et al. 1993). As mentioned later, these levels are tightly regulated by dynamic synthesis and degradation mechanisms.

The production of LPA is controlled by different phospholipase pathways (Aoki et al. 2002). However, studies in mice and human revealed that majority of extracellular LPA is produced by the secreted glycosylated enzyme lysophospholipase-D (LYSO-PLD) (van Meeteren et al. 2006, Benesch et al. 2015). LYSO-PLD is identical to a soluble form of cell motility-stimulating factor autotaxin and synthesizes LPA from lysophosphatidylcholine (the most abundant lysophospholipid precursor in plasma, $\sim 200 \mu \mathrm{M}$ ) or from lysophosphatidylserine and lysophosphatidylethanolamine (Aoki et al. 2002).

The mechanism of LPA signaling was not elucidated until 1996 when the first LPA receptor was cloned (Hecht et al. 1996). The bioactive fraction of LPA is bound to albumin and gelsolin in circulation (Meerschaert et al. 1998) and this may have an important impact on its bioavailability and binding to specific receptors. It is known that LPA exerts its action through different G-protein-coupled receptors (Yung et al. 2014). Up to now, there are six bona fide LPA receptors. From these receptors, LPA1, 2 and 3 belong to the Edg family, while LPA4, 5 and 6 are classified into non-Edg receptors from the purinergic family (P2Y). Other orphan G-proteincoupled receptors are proposed to facilitate LPA signaling (GPR35, GPR87, P2Y10 and RAGE) (Benesch et al. 2018).

Most cells express different combinations of LPA receptors that share intracellular signaling pathways dependent on heterotrimeric G-proteins including Goi, Go12/13, Goq and Gas (Noguchi et al. 2009). LPA receptors are expressed in different cell types amplifying the possibility of its action. Moreover, activation of LPA receptors modulates downstream effectors such as adenylyl cyclase, cAMP, intracellular $\mathrm{Ca}^{2+}$, mitogenactivated protein kinases, phospholipase C, PI3K/AKT and small GTPases (Ras, Rho, Rac) (Ishii et al. 2004). Due to these signaling characteristics, LPA regulates multiple cellular processes as cell survival, proliferation, cytoskeleton re-arrangement, motility, cytokine secretion and cell differentiation. Therefore, LPA redundancy has to be considered carefully according to each physiological and pathological situations. 
Extracellular LPA signaling is rapidly terminated through degradation by a family of three transmembrane exophosphatases known as lipid phosphate phosphatases which convert LPA into inorganic phosphate and monoacylglycerol by dephosphorylation (Benesch et al. 2015).

\section{LPA as a vascular mediator}

Lipids are not encoded in the genome. Therefore, genetic studies performed to dissect the importance of lipid signaling in physiology and pathology have been directed toward their receptors, transporters and metabolizing enzymes. Analysis of transgenic mice revealed that lipid mediators are involved in a wide range of physiological events including inflammation, immunity and angiogenesis. Moreover, vascular network formation is precisely controlled by pro- and anti-angiogenic molecules and lipid factors.

LPA could be considered a 'vascular lipid' since it is mainly produced by platelets and its metabolic pathways depend on extracellular enzymes present in circulation. Early in 1960, it was reported that a new vasopressor factor induced the contraction of isolated rabbit duodenum preparations (Khairahllah \& Page 1960). The authors observed that this factor was different from adrenergic amines and pressor polypeptides and was probably a lysophosphatide produced by an enzymatic reaction in plasma. They also described that similar vasopressor effects could be produced by the action of rattlesnake venom on lecithin. After 18 years, the vasopressor factor in soybean lecithin was identified as LPA (Tokumura et al. 1978a). Since then, numerous works were published describing vascular actions of LPA in different in vitro and in vivo biological systems.

Studies performed in mice and human revealed that smooth muscle cells (Panchatcharam et al. 2008, Subramanian et al. 2010, Dancs et al. 2017), endothelial cells (Zhou et al. 2011) and platelets (Haserück et al. 2004, Pamuklar et al. 2008) present in the vasculature respond to LPA (Cheng et al. 2009, Morris et al. 2009a,b). These interactions are involved in the regulation of blood vessel development and contribute to vascular biology and pathology (Mueller et al. 2015). Moreover, the effect of LPA on the vasculature has been also demonstrated in cat, rabbit, guinea pig (Tokumura et al. 1978b) and nonmammal species such as zebrafish (Yukiura et al. 2011).

As mentioned earlier, a wide range of actions of LPA in vascular events was discerned from studies involving transgenic mice. Both downregulation and overexpression of LYSO-PLD produce defects in angiogenesis triggering embryonic lethality due to severe vascular phenotype in the yolk sac and embryos as well as neural tube defects at embryonic day 9.5-10 (Tanaka et al. 2006, van Meeteren et al. 2006, Koike et al. 2011, Yukiura et al. 2015). Single and multiple deletions of LPA receptors produce differing vascular phenotypes. While
LPA1 and LPA4 double knockdown embryos exhibit vascular defects similar to Lyso-PLD knockdown, LPA4knockout mice are embryonic lethal due to hemorrhages and edema. Nevertheless, their phenotypes are not as severe as Lyso-PLD-knockout mice (Sumida et al. 2010). Endothelial-specific lipid phosphate phosphatases3-knockout mice also exhibit lethal vascular leakage and hemorrhage as observed in Lyso-PLD knockout and overexpressing mice (Panchatcharam et al. 2014, Chatterjee et al. 2016).

Altogether, these data strongly suggest that LPA turnover and action via its receptors are complex mechanisms by which vascular adaptations could be regulated.

\section{LPA relevance in vascular remodeling at the maternal-fetal interface}

\section{Studies in animal models - in vivo}

The relevance of LPA-LPA3 in embryo implantation was first reported by Ye et al. (2005). These authors performed elegant studies identifying strong phenotypic changes in Lpa3-deficient mice such as reduced litter size, altered positioning or crowding of embryos and embryonic death. On the other hand, Lpa1 and Lpa2 deletion shows no effects on embryo implantation, revealing other roles for these receptors (Contos et al. 2000, 2002). These results suggest that LPA3 is the major LPA receptor involved in embryo implantation (Ye et al. 2005, 2011, Wei et al. 2009, Achache et al. 2010). To explore this possibility, we examined the role of LPA3 at the sites of implantation in an in vivo rat model. The intrauterine administration of an LPA3 antagonist to pregnant rats in day 5 of gestation causes profound alterations in the vasculature and decidual damage that affects placental and embryo development (Sordelli et al. 2017). Interestingly, we observed a dissimilar vascularization pattern between the resorbed units compared with controls. The LPA3 antagonist decreased the cross-sectional length of uterine and arcuate arteries, suggesting a decline in the supply of nutrients and oxygen to the developing embryos being finally resorbed. In addition, the microvasculature is also altered. Resorbed implantation sites and placentas present fewer vessels, and these vessels show larger perimeter. We speculate that this could provoke increased oxygen levels with subsequent excessive oxidative stress that induces inflammation and resorption. In this sense, Plaisier et al. (2009) reported that decidual vascularization differs between fertile women and those who miscarry (i.e. fewer vessels with a larger circumference in miscarriages). In line with this, Sharkey et al. (2000) demonstrated that oxygen concentration modulates the architecture of the vasculature as well as the expression of certain angiogenic molecules. Furthermore, LPA3 blockade decreased II-10, Vegf-a and Vegf-r1 mRNA levels in resorbed implantation sites, indicating that macro 
and microvascular changes after the administration of the LPA3 antagonist are accompanied by molecular alterations (Sordelli et al. 2017).

Defects in the angiogenic process due to LPA3 antagonism are paralleled by histological anomalies in decidua and placenta (Sordelli et al. 2017). Decidual and placental damage is characterized by cellular disorganization, hemorrhage, fibrin deposition and the infiltration of neutrophils, which are typical events associated with embryo resorption. Since the decidua supports embryo growth until the placenta is entirely formed and secretes molecules that participate in neovascularization, failures in vascular and decidual formation seriously compromise the success of early pregnancy. Therefore, we hypothesize that the defects described in uterine and arcuate arteries affect decidualization and placentation.

Our findings together with those obtained from other authors suggest that endogenous LPA regulates decidualization and angiogenesis at the maternal-fetal interface. Moreover, LPA3 blockade produces significant irreversible post-implantation defects (embryo crowding and fetal resorption), indicating that this receptor might be involved in mechanisms associated with the development of the embryo and its supporting tissues. Interestingly, Lpa3-knockout mice exhibit similar phenotypic changes (Ye et al. 2005). Ye et al. (2005) also demonstrated that the expression of cyclooxygenase-2 (COX-2), as well as the production of prostaglandin $\mathrm{E} 2$, are reduced in Lpa3-deficient uteri. Two years later, Hama et al. (2007) showed that LPA-LPA3 signaling participates in implantation timing and embryo spacing independently. Prostaglandins are crucial regulators of uterine contractions which are necessary for embryo spacing. Therefore, altogether these observations support the notion that, besides angiogenesis and decidualization, LPA3 receptor might be also involved in the contractions that allow accurate location of the embryos along the uterine horn.

The relevance of LPA during gestation has been demonstrated in other mammalian species. LPA is locally produced in the endometrium of cows (Woclawek-Potocka et al. 2009). Also, LPA regulates the ratio of prostaglandin E2/prostaglandin F2 alpha in the bovine uterus. This mechanism seems to be involved in the luteotropic effect of LPA as it stimulates the secretion of progesterone from the bovine corpus luteum (Woclawek-Potocka et al. 2010). In addition, it has been described that the porcine uterus expresses the LYSO-PLD enzyme which regulates the synthesis of LPA locally (Seo et al. 2012). This result suggests that LPA participates in the interaction between the mother and the conceptus in pigs.

In conclusion, disruption of endogenous LPA signaling modifies uterine vasculature development with detrimental consequences in decidualization, placenta development and embryo growth.

\section{Studies in animal models - in vitro}

As mentioned, several evidences suggest that LPA is a key factor in embryo implantation (Ye et al. 2005, 2011, Wei et al. 2009, Achache et al. 2010). Taking this knowledge into account, during the last years our group described that LPA promotes blastocyst implantation regulating pivotal events as decidualization and vascular remodeling during early gestation. We demonstrated that LPA modulates the level of important lipid mediators, namely prostaglandins, that prepare uterine milieu for embryo invasion during the window of implantation in the rat (Sordelli et al. 2012). The incubation of uterine strips obtained from pregnant rats on day 5 of gestation with LPA increases the production of COX-2 derived prostaglandin E2. Prostaglandin E2 and prostacyclin synthetized by COX-2 increase vascular permeability, being pro-angiogenic factors during early gestation in mice (Matsumoto et al. 2002, Sookvanichsilp \& Pulbutr 2002). In addition, we described that the LPA effect is mediated by LPA3 in the rat uterus. LPA3 is confined to the glandular and luminal epithelium of the endometrium, being the latter expressed in maternal tissues in close contact with the invasive trophoblast (Sordelli et al. 2012). The fact that LPA3 is differentially regulated during the peri-implantation period (day 4 vs day 5 and day 6 of gestation) indicates that the expression of this receptor might depend on the presence of the blastocyst and its state of activation. Interestingly, the endometrium from women with recurrent implantation failure showed reduced LPA3 and COX-2 levels (Achache et al. 2010). Hence, LPA3 seems to be the subtype of LPA receptor with major participation during early gestation.

Afterward, we studied the role of nitric oxide that has been described as an important regulator of vascular biology in different physiological and pathological conditions. Nitric oxide synthase (NOS) catalyzes nitric oxide production and exists in three isoforms: endothelial NOS, neuronal NOS and inducible NOS (iNOS). In this sense, we observed that LPA increases the production of nitric oxide in the rat uterus as augments iNOS activity through the activation of LPA3 receptor (Beltrame et al. 2013). Also, NOS activity is increased at the sites of embryo implantation and depends on the presence of the blastocyst (Sordelli et al. 2011). Other authors reported that the regulation of nitric oxide tone and NOS expression is associated to vascularization defects leading to reduced implantation rates in the rat uterus (Ota et al. 1999, Purcell et al. 1999). Moreover, iNOS and COX-2 signaling pathways interact downstream the LPA effect, which is relevant for the physiology and progress of decidualization and angiogenesis (Beltrame et al. 2013). Interestingly, we found that LPA increases the expression of $\operatorname{lgfbp}-1$ and $I /-10$ in the rat uterus (Sordelli et al. 2012) reinforcing the hypothesis that LPA is a local regulator of implantation (Fig. 4). This was the first time that LPA was related to the transformation of the 


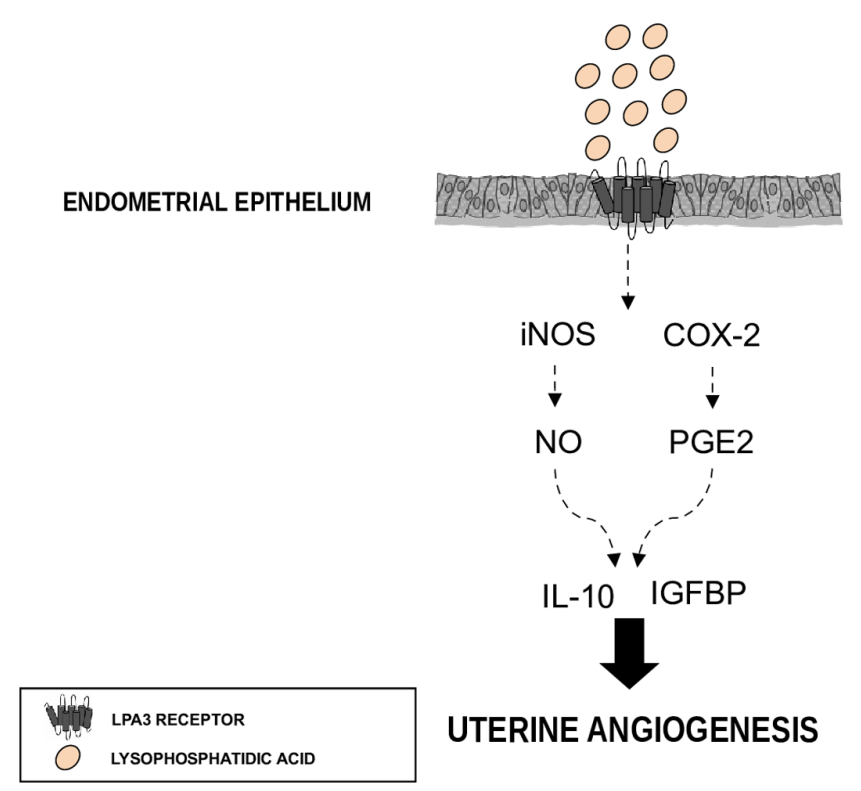

Figure 4 LPA regulates uterine angiogenesis in the rat uterus. LPA induces the activation of COX-2 and prostaglandin E2 synthesis and increases iNOS-derived nitric oxide. These pathways seem to regulate decidualization and angiogenesis through LPA3 receptors at implantation sites. COX-2, cyclooxygenase-2; iNOS, inducible nitric oxide synthase; NO, nitric oxide; PGE2, prostaglandin E2.

stroma into decidual cells. During decidualization, cells undergo highly active apoptosis and differentiation and LPA could promote these processes in other biological systems (Noguchi et al. 2009). The relevance of LPA in decidualization has been recently confirmed in mice by Aikawa and colleagues who demonstrated that LYSOPLD/LPA/LPA3 signaling induces decidualization via the canonical HB-EGF and COX-2 pathways at the embryo epithelial boundary (Aikawa et al. 2017). LPA is produced near embryo implantation sites and activates LPA3 localized at the epithelial layer of the uterine endometrium in mice. The regulatory pathway activated by LPA finally induces the stromal layer and leads to the decidual reaction.

Overall, these results reinforce the hypothesis about LPA action at the maternal-fetal interface.

\section{Studies performed in human cell lines}

The results detailed before suggest that LPA may play a pivotal role in endometrium and placental angiogenesis in rodents. In fact, spatiotemporal and reciprocal interactions between the trophoblast and endothelium are required for angiogenesis during early gestation. Thus, abnormal LPA signaling at the beginning of implantation may result in aberrant regulation of endothelial adaptations, trophoblast functions and vascular remodeling leading to placental abruption, fetal demise and pregnancy loss.

Several authors reported that LPA is present at high concentration in different fluids during reproductive processes. Along gestation, serum LYSO-PLD activity increases in pregnant women and decreases to nonpregnant levels soon after delivery (Tokumura et al. 2002a). Therefore, the group of Iwasawa et al. (2009) proposed that the placental trophoblast is the main source of LPA during gestation. Additionally, LPA is present in human follicular fluid (Tokumura et al. 1999) and at micromolar concentrations in uterine flushings of domestic mammals (Seo et al. 2008, Liszewska et al. 2009).

As highlighted before, vessel remodeling requires interaction between diverse cell types and mediators from the maternal and fetal components. Much effort is being made to unravel the mechanisms by which invasive first trimester cytotrophoblast changes its phenotype to an endovascular one, and how the invasive and endovascular trophoblast transforms the spiral arteries. However, due to difficulties in studying early human pregnancy, the regulatory pathways that modulate cytotrophoblast behavior and contribute to spiral artery remodeling remains to be determined. The LPA role in endovascular profile acquisition by human first trimester trophoblast and in the interaction between endovascular trophoblast and endothelial cells were therefore examined. LPA via LPA3 stimulates HTR-8/ SVneo cell line endovascular differentiation, migration and proliferation (Beltrame et al. 2018a). COX-2 participates in LPA-increased trophoblast tubulogenesis and LPA augments COX-2 nuclear accumulation without changes in its distribution (Beltrame et al. 2018a). Other studies reveal COX-2 nuclear localization, suggesting a role for this enzyme in regulating gene expression (Parfenova et al. 2001). Interestingly, prostaglandin E2 stimulates HTR-8/SVneo tubulogenesis, while prostaglandin F2alpha does not affect this process. It has been suggested that prostaglandin E2 contributes to maternal decidualization and angiogenesis, whereas prostaglandin F2alpha promotes uterine contractions with adverse consequences for embryo implantation (Hamilton \& Kennedy 1994, Stocco \& Deis 1998, Callegari et al. 2005). Moreover, COX-2 selective inhibition in LPA-induced trophoblast tubulogenesis is rescued by the incubation with prostaglandin E2, highlighting that this prostaglandin is the main COX-2derived prostanoid involved in LPA effect on trophoblast tube formation (Beltrame et al. 2018a).

As COX-2, iNOS isoform participates in LPA-increased trophoblast tubulogenesis, is localized in HTR-8/SVneo nucleus and LPA increases its protein level (Beltrame et al. 2018a). This tied in with evidence from other authors demonstrating a specific role for nitric oxide in vascular adaptations for a healthy pregnancy (Dunk et al. 2000, Xu et al. 2014). In particular, Zhou et al. (1997a) show that nitric oxide promotes cytotrophoblast endovascular invasion. Notably, nitric oxide is produced by the trophoblast while invading the maternal spiral arteries in the wall of the uterus (Al-Hijji et al. 2003). 

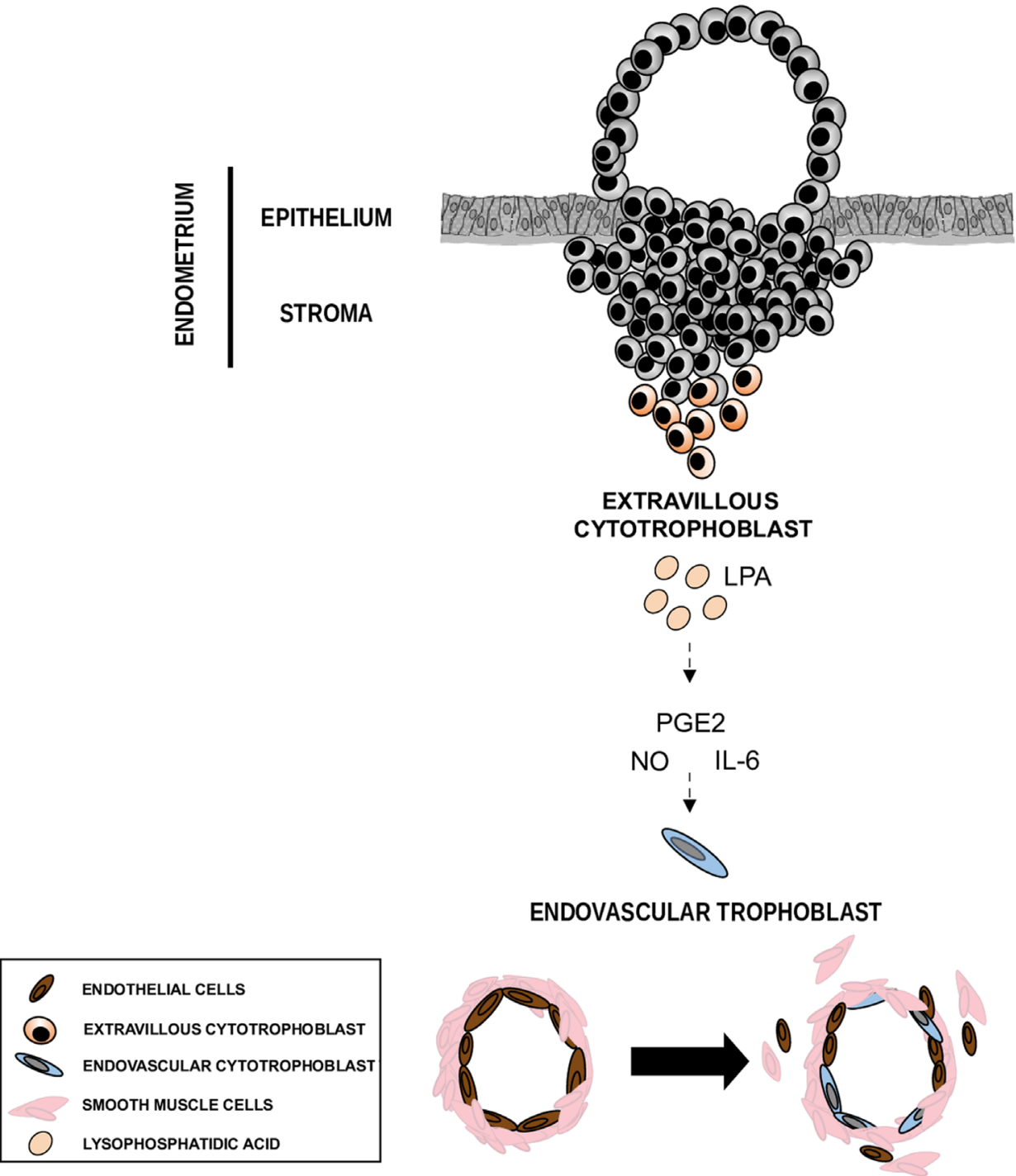

ENDOVASCULAR DIFFERENTATION

SPIRAL ARTERY REMODELING

Figure 5 LPA and vascular remodeling. LPA promotes the acquisition of trophoblast endovascular phenotype by a mechanism involving PGE2, nitric oxide and IL-6. In addition, LPA-induced endovascular phenotype stimulates the release of soluble factors that induce endothelial cells migration away from spiral arteries. NO, nitric oxide; PGE2, prostaglandin-E2.

Based on these findings, we hypothesize that LPA produced at the maternal-fetal interface induces COX-2 derived prostaglandin E2 production and nitric oxide by iNOS promoting endovascular trophoblast differentiation. This mechanism might support cytotrophoblast participation in spiral artery remodeling, in order to sustain blood flow due to the increased metabolic demands of the embryo.

Remarkably, LPA seems to modulate another crucial step in spiral artery remodeling. This lipid mediator promotes in vitro the crosstalk between human first trimester endovascular trophoblast and endothelial cells and induces the release of trophoblast-soluble factors derived from COX-2 and IL-6 pathways, which finally stimulate migration of endothelial cells without affecting apoptosis (Fig. 5). The change in trophoblast phenotype triggered by LPA and not LPA itself modulates trophoblast-endothelial dialog (Beltrame et al. 2019). COX-2 but not iNOS participates in the interaction between trophoblast and endothelium downstream LPA. Nitric oxide seems to modulate cytotrophoblast behavior without obvious effects on the interaction between endovascular trophoblast and the endothelium (Beltrame et al. 2018a, 2019). On the other hand, COX-2 is an active factor in vascular processes in different biological systems, and it is well known that COX-2-derived soluble factors induce endothelial cells migration (Daniel et al. 1999, Zhao et al. 2012). The relevance of LPA-COX-2 pathway is highlighted in $\mathrm{LPA}^{-/-}$mice where COX-2 expression in 
the uterus is decreased and administration of exogenous prostaglandin E2 and prostacyclin restores most of the normal phenotype (Ye et al. 2005). Altogether, these data point out the importance of prostaglandin E2 in the vascular remodeling processes during early gestation.

Within the wide range of mediators involved in vascular adaptations, different authors demonstrate the importance of cytokines in these processes. HTR-8/SVneo trophoblast cells as well as the syncytiotrophoblast and cytotrophoblast secrete IL-6 and express its receptor (Kameda et al. 1990, Jovanovic \& Vicovac 2009, Champion et al. 2012). LPA increases II-6 mRNA which participates in HTR-8/SVneo capillarylike tube formation (Beltrame et al. 2019). Moreover, IL-6 mediates LPA-induced trophoblast-endothelial crosstalk and COX-2 mediates the increment in its expression. Interestingly, LPA increases II-6 mRNA, but does not modify other vascular cytokines (II-8, Vegf-C, Vegf-a) in HTR-8/SVneo. Also, the group of Weiss et al. (2016) reported that IL-6 might be a chemoattractant factor guiding trophoblast cells toward endothelial cells. These observations together suggest a preponderant role for IL-6 in vascular remodeling at the maternal-fetal interface (Fig. 5).

Sex steroids orchestrate most of the reproductive events in mammals. In particular, progesterone and estradiol are in extremely high concentrations in maternal circulation and have an important role to accomplish proper maternal vascular adaptations during early pregnancy (Clark et al. 2017). Although it has been reported that progesterone and estradiol modulate uterine arteries remodeling and placental angiogenesis (Chen et al. 2012, Maliqueo et al. 2016), their specific role in vascular remodeling at the maternal-fetal interface remains controversial. In this sense, we observed that progesterone and estradiol regulate HTR-8/SVneo trophoblast capillary-like structures formation in a concentration-dependent manner and only a specific combination of progesterone + estradiol $\left(10^{-7} \mathrm{M}+10^{-5} \mathrm{M}\right)$ stimulates tube formation (Beltrame et al. 2018b). This sex steroid-triggered tubulogenesis could be modulated directly or indirectly by mechanisms associated with LPA/LPA3 pathway (Beltrame et al. 2018b). Particularly, progesterone+estradiol effect is partially mediated by an increase in LPA production that activates at least LPA3 receptor expressed in HTR-8/ SVneo cells. Studies in mice reveal that the balance of progesterone and estrogen signaling is disrupted in Lpa3 knock out uterus and leads to delayed embryo implantation (Diao et al. 2015). Therefore, there might be a fine regulation of steroid hormones tone during endovascular differentiation at the maternal-fetal interface. This reinforces the notion that the balance of female sex hormones is critical for pregnancy establishment and modifications in the circulating levels could lead to poor pregnancy outcomes (Lim

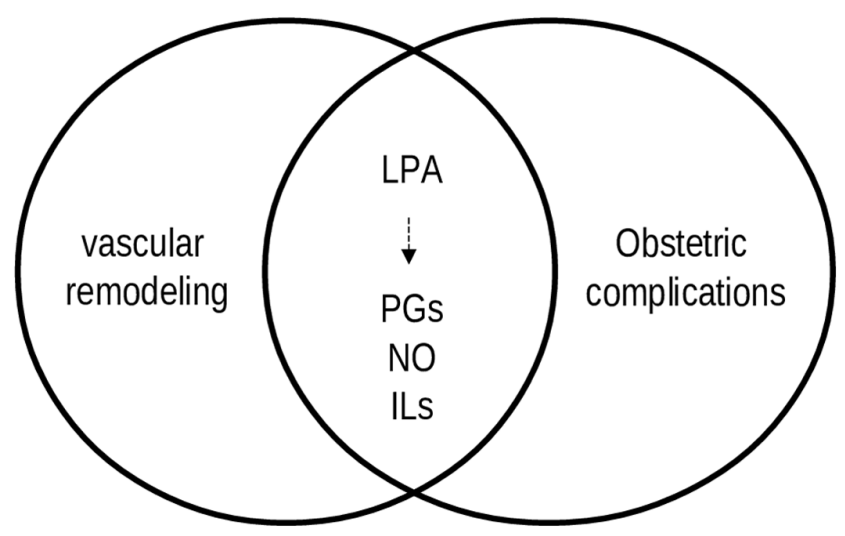

Figure 6 Importance of LPA signaling during early gestation. LPA and the molecules activated downstream modulate vascular events at the implantation site which seem to be relevant for a successful gestation. ILs, interleukins; NO, nitric oxide; PGs, prostaglandins.

\& Wang 2010, Ramathal et al. 2010, Cha et al. 2012, Maliqueo et al. 2016). Interestingly, progesterone at highest concentrations alone or in combination with estradiol suppresses basal tubular formation (Beltrame et al. 2018b). In this regard, it has been reported that preeclampsia, a pathology associated with vascular insufficiencies, is correlated with higher progesterone levels (Walsh \& Coulter 1989). Based on these data, LPA/ LPA3 appears as a key system that could be triggered downstream by steroid hormones.

Altogether, these data strongly suggest that inadequate endovascular trophoblast differentiation or abnormal interaction with spiral arteries endothelium due to aberrant LPA signaling may contribute to pathologies related to vascular deficiencies.

\section{Conclusions}

Observations in several experimental models show that LPA plays a crucial role in regulating vascular biology and pathology. Vascular remodeling at the maternal-fetal interface is essential to achieve normal gestation. This review presents evidence that supports the participation of LPA in the vascular adaptations that occur during early gestation, ensuring the adequate blood flow to sustain normal growth of the embryo. Elucidating the interaction between LPA and the molecules regulated downstream would provide new insights into the significance of LPA signaling in the vascular events that lead to a successful pregnancy. Therefore, we propose a new role for LPA as a pivotal lipid that could be related to severe obstetric complications associated with vascular diseases (Fig. 6).

\section{Declaration of interest}

The authors declare that there is no conflict of interest that could be perceived as prejudicing the impartiality of this review. 


\section{Funding}

The results described here were supported by research grants from Scientific and Technological Research Fund (FONCyT) PICT (2013 N0285), PIP (2015 N0100764) to M L Ribeiro and Roemmers Foundation and PICT $\left(2016 \mathrm{~N}^{\circ} 041\right)$ to M S Sordelli. The funders had no role in the study design, data collection and analysis, preparation of the manuscript or decision to publish.

\section{Author contribution statement}

J S B and M L R conceived the review. J S B, M S S and M L R wrote the manuscript. M S S and V A C corrected the text. J S B and M S S performed experiments. J S B and M L R analyzed the data. MS S and M L R contributed with their research grants.

\section{References}

Achache H, Tsafrir A, Prus D, Reich R \& Revel A 2010 Defective endometrial prostaglandin synthesis identified in patients with repeated implantation failure undergoing in vitro fertilization. Fertility and Sterility 94 1271-1278. (https://doi.org/10.1016/j.fertnstert.2009.07.1668)

Aikawa S, Kano K, Inoue A, Wang J, Saigusa D, Nagamatsu T, Hirota Y, Fujii T, Tsuchiya S, Taketomi Y et al. 2017 Autotaxin-lysophosphatidic acid-LPA3 signaling at the embryo-epithelial boundary controls decidualization pathways. EMBO Journal 36 2146-2160. (https://doi. org/10.15252/embj.201696290)

Akira T, Kengo H, Kenji F \& Hiroaki T 1986 Involvement of lysophospholipase D in the production of lysophosphatidic acid in rat plasma. Biochimica and Biophysica Acta 875 31-38. (https://doi. org/10.1016/0005-2760(86)90007-X)

Al-Hijii J, Andolf E, Laurini R \& Batra S 2003 Nitric oxide synthase activity in human trophoblast, term placenta and pregnant myometrium. Reproductive Biology and Endocrinology 28 1-51. (https://doi. org/10.1186/1477-7827-1-51)

Aoki J, Taira A, Takanezawa Y, Kishi Y, Hama K, Kishimoto T, Mizuno K, Saku K, Taguchi R \& Arai H 2002 Serum lysophosphatidic acid is produced through diverse phospholipase pathways. Journal of Biological Chemistry 277 48737-48744. (https://doi.org/10.1074/jbc.M206812200)

Baker DL, Umstot ES, Desiderio DM \& Tigyi GJ 2000 Quantitative analysis of lysophosphatidic acid in human blood fractions. Annals of the New York Academy of Sciences 905 267-269. (https://doi. org/10.1111/j.1749-6632.2000.tb06557.x)

Beltrame JS, Sordelli MS, Cella M, Perez Martinez S, Franchi AM \& Ribeiro ML 2013 Lysophosphatidic acid increases the production of pivotal mediators of decidualization and vascularization in the rat uterus. Placenta 34 751-756. (https://doi.org/10.1016/j.placenta.2013.06.001)

Beltrame JS, Sordelli MS, Cañumil VA, Franchi AM \& Ribeiro ML 2018a Lysophosphatidic acid-triggered pathways promote the acquisition of trophoblast endovascular phenotype in vitro. Journal of Cellular Biochemistry 119 758-772. (https://doi.org/10.1002/jcb.26239)

Beltrame JS, Sordelli MS, Cañumil VA, Alonso CAI, Perez Martinez S \& Ribeiro ML 2018b Steroid hormones induce in vitro human first trimester trophoblast tubulogenesis by the lysophosphatidic acid pathway. Molecular and Cellular Endocrinology 478 126-132. (https:// doi.org/10.1016/j.mce.2018.08.003)

Beltrame JS, Scotti L, Sordelli MS, Cañumil VA, Franchi AM, Parborell F \& Ribeiro ML 2019 Lysophosphatidic acid induces the crosstalk between the endovascular human trophoblast and endothelial cells in vitro. Journal of Cellular Physiology 234 6274-6285. (https://doi.org/10.1002/ jcp.27358)

Benesch MG, Zhao YY, Curtis JM, McMullen TP \& Brindley DN 2015 Regulation of autotaxin expression and secretion by lysophosphatidate and sphingosine 1-phosphate. Journal of Lipid Research $\mathbf{5 6}$ 1134-1144. (https://doi.org/10.1194/jlr.M057661)

Benesch MGK, MacIntyre ITK, McMullen TPW \& Brindley DN 2018 Coming of age for autotaxin and lysophosphatidate signaling: clinical applications for preventing, detecting and targeting tumor-promoting inflammation. Cancers 10 73-98. (https://doi.org/10.3390/cancers10030073)

Benirschke K \& Kaufmann P 2000 Pathology of the Human Placenta, 4th ed., p. 1050. Springer.

Blaho VA \& Chun J 2018 'Crystal' clear? Lysophospholipid receptor structure insights and controversies. Trends in Pharmacological Sciences 39 953-966. (https://doi.org/10.1016/j.tips.2018.08.006)

Boyd JD \& Hamilton WJ 1970 The Human Placenta. Cambridge: W. Heffer \& Sons.

Burrows TD, King A \& Loke YW 1994 Expression of adhesion molecules by endovascular trophoblast and decidual endothelial cells: implications for vascular invasion during implantation. Placenta 15 21-33. (https:// doi.org/10.1016/S0143-4004(05)80233-4)

Callegari EA, Ferguson-Gottschall S \& Gibori G 2005 PGF2a induced differential expression of genes involved in turnover of extracellular matrix in rat decidual cells. Reproductive Biology and Endocrinology 3 3. (https://doi.org/10.1186/1477-7827-3-3)

Cartwright JE \& Whitley GS 2017 Strategies for investigating the maternalfetal interface in the first trimester of pregnancy: what can we learn about pathology? Placenta 60 145-149. (https://doi.org/10.1016/j. placenta.2017.05.003)

Cartwright JE, Fraser R, Leslie K, Wallace AE \& James JL 2010 Remodelling atthematernal-fetal interface: relevancetohuman pregnancy disorders. Reproduction 140 803-813. (https://doi.org/10.1530/ REP-10-0294)

Cha J, Sun X \& Dey SK 2012 Mechanisms of implantation: strategies for successful pregnancy. Nature Medicine 18 1754-1767. (https://doi. org/10.1038/nm.3012)

Champion H, Innes BA, Robson SC, Lash GE \& Bulmer JN 2012 Effects of interleukin- 6 on extravillous trophoblast invasion in early human pregnancy. Molecular Human Reproduction 18 391-400. (https://doi. org/10.1093/molehr/gas010)

Chatterjee I, Baruah J, Lurie EE \& Wary KK 2016 Endothelial lipid phosphate phosphatase-3 deficiency that disrupts the endothelial barrier function is a modifier of cardiovascular development. Cardiovascular Research 111 105-118. (https://doi.org/10.1093/cvr/cvw090)

Chen JZ, Sheehan PM, Brennecke SP \& Keogh RJ 2012 Vessel remodelling, pregnancy hormones and extravillous trophoblast function. Molecular and Cellular Endocrinology 349 138-144. (https://doi.org/10.1016/j. mce.2011.10.014)

Cheng Y, Makarova N, Tsukahara R, Guo H, Shuyu E, Farrar P, Balazs L, Zhang C \& Tigyi G 2009 Lysophosphatidic acid-induced arterial wall remodeling: requirement of PPARgamma but not LPA1 or LPA2 GPCR. Cellular Signalling 21 1874-1884. (https://doi.org/10.1016/j. cellsig.2009.08.003)

Choi JW, Herr DR, Noguchi K, Yung YC, Lee CW, Mutoh T, Lin ME, Teo ST, Park KE, Mosley AN et al. 2010 LPA receptors: subtypes and biological actions. Annual Review of Pharmacology and Toxicology 50 157-186. (https://doi.org/10.1146/annurev.pharmtox.010909.105753)

Clark NC, Pru CA \& Pru JK 2017 Novel regulators of hemodynamics in the pregnant uterus. Progress in Molecular Biology and Translational Science 145 181-216. (https://doi.org/10.1016/bs.pmbts.2016.12.007)

Contos JJ, Fukushima N, Weiner JA,Kaushal D \& Chun J 2000 Requirement for the IpA1 lysophosphatidic acid receptor gene in normal suckling behavior. PNAS 97 13384-13389. (https://doi.org/10.1073/ pnas.97.24.13384)

Contos JJ, Ishii I, Fukushima N, Kingsbury MA, Ye X, Kawamura S, Brown JH \& Chun J 2002 Characterization of Ipa(2) (Edg4) and Ipa(1)/ Ipa(2) (Edg2/Edg4) lysophosphatidic acid receptor knockout mice: signaling deficits without obvious phenotypic abnormality attributable to Ipa(2). Molecular and Cellular Biology 22 6921-6929. (https://doi. org/10.1128/mcb.22.19.6921-6929.2002)

Da Silva-Arnold S, James JL, Al-Khan A, Zamudio S \& Illsley NP 2015 Differentiation of first trimester cytotrophoblast to extravillous trophoblast involves an epithelial-mesenchymal transition. Placenta 36 1412-1418. (https://doi.org/10.1016/j.placenta.2015.10.013)

Dancs PT, Ruisanchez É, Balogh A, Panta CR, Miklós Z, Nüsing RM, Aoki J, Chun J, Offermanns S, Tigyi G et al. 2017 LPA1 receptormediated thromboxane A2 release is responsible for lysophosphatidic acid-induced vascular smooth muscle contraction. FASEB Journal 31 1547-1555. (https://doi.org/10.1096/fj.201600735R) 
Daniel TO, Liu H, Morrow JD, Crews BC \& Marnett LJ 1999 Thromboxane A2 is a mediator of cyclooxygenase-2-dependent endothelial migration and angiogenesis. Cancer Research 59 4574-4577.

Demir R, Yaba A \& Huppertz B 2010 Vasculogenesis and angiogenesis in the endometrium during menstrual cycle and implantation. Acta Histochemica 112 203-214. (https://doi.org/10.1016/j.acthis.2009.04.004)

Dey SK \& Lim H 2006 Implantation. In Physiology of Reproduction, pp 147-188. Eds E Knobil \& J Neill. St. Louis, MO: Elsevier Academic Press.

Diao H, Li R, El Zowalaty AE, Xiao S, Zhao F, Dudley EA \& Ye X 2015 Deletion of lysophosphatidic acid receptor 3 (Lpar3) disrupts fine local balance of progesterone and estrogen signaling in mouse uterus during implantation. Biology of Reproduction 93 123. (https://doi.org/10.1095/ biolreprod.115.131110)

Dunk C, Shams M, Nijjar S, Rhaman M, Qiu Y, Bussolati B \& Ahmed A 2000 Angiopoietin-1 and angiopoietin-2 activate trophoblast Tie-2 to promote growth and migration during placental development. American Journal of Pathology 156 2185-2199. (https://doi.org/10.1016/S00029440(10)65089-4)

Eichholtz T, Jalink K, Fahrenfort I \& Moolenaar WH 1993 The bioactive phospholipid lysophosphatidic acid is released from activated platelets. Biochemical Journal 291 677-680. (https://doi.org/10.1042/bj2910677)

Espinoza J, Romero R, Mee Kim Y, Kusanovic JP, Hassan S, Erez O, Gotsch F, Than NG, Papp Z \& Jai Kim C 2006 Normal and abnormal transformation of the spiral arteries during pregnancy. Journal of Perinatal Medicine 34 447-458. (https://doi.org/10.1515//PM.2006.089)

Gerrard JM \& Robinson P 1989 Identification of the molecular species of lysophosphatidic acid produced when platelets are stimulated by thrombin. Biochimica and Biophysica Acta 1001 282-285. (https://doi. org/10.1016/0005-2760(89)90112-4)

Hama K, Aoki J, Inoue A, Endo T, Amano T, Motoki R, Kanai M, Ye X, Chun J, Matsuki $\mathbf{N}$ et al. 2007 Embryo spacing and implantation timing are differentially regulated by LPA3-mediated lysophosphatidic acid signaling in mice. Biology of Reproduction 77 954-959. (https://doi. org/10.1095/biolreprod.107.060293)

Hamilton GS \& Kennedy TG 1994 Uterine vascular changes after unilateral intrauterine infusion of indomethacin and prostaglandin E2 to rats sensitized for the decidual cell reaction. Biology of Reproduction $\mathbf{5 0}$ 757-764. (https://doi.org/10.1095/biolreprod50.4.757)

Harris LK, Keogh RJ, Wareing M, Baker PN, Cartwright JE, Aplin JD \& Whitley GS 2006 Invasive trophoblasts stimulate vascular smooth muscle cell apoptosis by a Fas ligand-dependent mechanism. American Journal of Pathology 169 1863-1874. (https://doi.org/10.2353/ ajpath.2006.060265)

Haserück N, Erl W, Pandey D, Tigyi G, Ohlmann P, Ravanat C, Gachet C \& Siess W 2004 The plaque lipid lysophosphatidic acid stimulates platelet activation and platelet-monocyte aggregate formation in whole blood: involvement of P2Y1 and P2Y12 receptors. Blood 103 2585-2592. (https://doi.org/10.1182/blood-2003-04-1127)

Hecht JH, Weiner JA, Post SR \& Chun J 1996 Ventricular zone gene-1 (vzg1) encodes a lysophosphatidic acid receptor expressed in neurogenic regions of the developing cerebral cortex. Journal of Cell Biology 135 1071-1083. (https://doi.org/10.1083/jcb.135.4.1071)

Hertig AT, Rock J \& Adams EC 1956 A description of 34 human ova within the first 17 days of development. American Journal of Anatomy 98 435-493. (https://doi.org/10.1002/aja.1000980306)

Ishii I, Fukushima N, Ye X \& Chun J 2004 Lysophospholipid receptors: signaling and biology. Annual Review of Biochemistry 73 321-354. (https://doi.org/10.1146/annurev.biochem.73.011303.073731)

Iwasawa Y, Fujii T, Nagamatsu T, Kawana K, Okudaira S, Miura S, Matsumoto J, Tomio A, Hyodo H, Yamashita T et al. 2009 Expression of autotaxin, an ectoenzyme that produces lysophosphatidic acid, in human placenta. American Journal of Reproductive Immunology 62 90-95. (https://doi.org/10.1111/j.1600-0897.2009.00715.x)

Jovanovic M \& Vicovac L 2009 Interleukin-6 stimulates cell migration, invasion and integrin expression in HTR-8/SVneo cell line. Placenta 30 320-328. (https://doi.org/10.1016/j.placenta.2009.01.013)

Kam EP, Gardner L, Loke YW \& King A 1999 The role of trophoblast in the physiological change in decidual spiral arteries. Human Reproduction 14 2131-2138. (https://doi.org/10.1093/humrep/14.8.2131)

Kameda T, Matsuzaki N, Sawai K, Okada T, Saji F, Matsuda T, Hirano T, Kishimoto T \& Tanizawa O 1990 Production of interleukin-6 by normal human trophoblast. Placenta 11 205-213. (https://doi.org/10.1016/ S0143-4004(05)80266-8)
Khairahllah PA \& Page IH 1960 A vasopressor lipid in incubated plasma. American Journal of Physiology 199 341-345. (https://doi.org/10.1152/ ajplegacy.1960.199.2.341)

Khong TY, De Wolf F, Robertson WB \& Brosens I 1986 Inadequate maternal vascular response to placentation in pregnancies complicated by pre-eclampsia and by small-for-gestational age infants. British Journal of Obstetrics and Gynaecology 93 1049-1059. (https://doi. org/10.1111/j.1471-0528.1986.tb07830.x)

Koike S, Yutoh Y, Keino-Masu K, Noji S, Masu M \& Ohuchi H 2011 Autotaxin is required for the cranial neural tube closure and establishment of the midbrain-hindbrain boundary during mouse development. Developmental Dynamics 240 413-421. (https://doi.org/10.1002/dvdy.22543)

Leach L, Badet J, Brownbill P, Harris L, Keogh R, Kalionis B \& Whitley G 2006 Endothelium, blood vessels and angiogenesis, a workshop report. Placenta 27 S26-S29. (https://doi.org/10.1016/j.placenta.2006.01.022)

Leblanc R, Houssin A \& Peyruchaud O 2018 2Platelets, autotaxin and lysophosphatidic acid signalling: win-win factors for cancer metastasis. British Journal of Pharmacology 175 3100-3110. (https://doi. org/10.1111/bph.14362)

Lim HJ \& Wang H 2010 Uterine disorders and pregnancy complications: insights from mouse models. Journal of Clinical Investigation $\mathbf{1 2 0}$ 1004-1015. (https://doi.org/10.1172/JCl41210)

Lindenberg S 1991 Experimental studies on the initial trophoblast endometrial interaction. Danish Medical Bulletin 38 371-380.

Liszewska E, Reinaud P, Billon-Denis E, Dubois O, Robin P \& Charpigny G 2009 Lysophosphatidic acid signaling during embryo development in sheep: involvement in prostaglandin synthesis. Endocrinology 150 422-434. (https://doi.org/10.1210/en.2008-0749)

Liu Y, Fan X, Wang R, Lu X, Dang YL, Wang H, Lin HY, Zhu C, Ge H, Cross JC et al. 2018 Single-cell RNA-seq reveals the diversity of trophoblast subtypes and patterns of differentiation in the human placenta. Cell Research 28 819-832. (https://doi.org/10.1038/s41422018-0066-y)

Lyall F 2005 Priming and remodelling of human placental bed spiral arteries during pregnancy: a review. Placenta 26 S31-S36. (https://doi. org/10.1016/j.placenta.2005.02.010)

Maliqueo M, Echiburú B \& Crisosto N 2016 Sex steroids modulate uterine-placental vasculature: implications for obstetrics and neonatal outcomes. Frontiers in Physiology 7 152. (https://doi.org/10.3389/ fphys.2016.00152)

Maltepe E \& Fisher SJ 2015 Placenta: the forgotten organ. Annual Review of Cell and Developmental Biology 31 523-552. (https://doi.org/10.1146/ annurev-cellbio-100814-125620)

Matsumoto H, Ma WG, Daikoku T, Zhao X, Paria BC, Das SK, Trzaskos JM \& Dey SK 2002 Cyclooxygenase-2 differentially directs uterine angiogenesis during implantation in mice. Journal of Biological Chemistry 277 29260-29267. (https://doi.org/10.1074/jbc.M203996200)

McMaster MT, Zhou Y \& Fisher SJ 2004 Abnormal placentation and the syndrome of pre-eclampsia. Seminars in Nephrology 24 540-547. (https://doi.org/10.1016/j.semnephrol.2004.07.002)

Meerschaert K, De Corte V, De Ville Y, Vandekerckhove J \& Gettemans J 1998 Gelsolin and functionally similar actin-binding proteins are regulated by lysophosphatidic acid. EMBO Journal 17 5923-5932. (https://doi.org/10.1093/emboj/17.20.5923)

Miller PB, Parnell BA, Bushnell G, Tallman N, Forstein DA, Higdon 3rd HL, Kitawaki J \& Lessey BA 2012 Endometrial receptivity defects during IVF cycles with and without letrozole. Human Reproduction 27 881-888. (https://doi.org/10.1093/humrep/der452)

Mills GB \& Moolenaar WH 2003 The emerging role of lysophosphatidic acid in cancer. Nature Reviews: Cancer 3 582-591. (https://doi. org/10.1038/nrc1143)

Moolenaar WH 1999 Bioactive lysophospholipids and their G proteincoupled receptors. Experimental Cell Research 253 230-238. (https:// doi.org/10.1006/excr.1999.4702)

Morris AJ, Selim S, Salous A \& Smyth SS 2009a Blood relatives: dynamic regulation of bioactive lysophosphatidic acid and sphingosine-1phosphate metabolism in the circulation. Trends in Cardiovascular Medicine 19 135-140. (https://doi.org/10.1016/j.tcm.2009.07.005)

Morris AJ, Panchatcharam M, Cheng HY, Federico L, Fulkerson Z, Selim S, Miriyala S, Escalante-Alcalde D \& Smyth SS 2009b Regulation of blood and vascular cell function by bioactive lysophospholipids. Journal of Thrombosis and Haemostasis 7 (Supplement 1) 38-43. (https://doi. org/10.1111/j.1538-7836.2009.03405.x) 
Mueller P, Ye S, Morris A \& Smyth SS 2015 Lysophospholipid mediators in the vasculature. Experimental Cell Research 333 190-194. (https://doi. org/10.1016/j.yexcr.2015.03.016)

Noguchi K, Herr D, Mutoh T \& Chun J 2009 Lysophosphatidic acid (LPA) and its receptors. Current Opinion in Pharmacology 9 15-23. (https:// doi.org/10.1016/j.coph.2008.11.010)

Ota H, Igarashi S, Oyama N, Suzuki Y \& Tanaka T 1999 Optimal levels of nitric oxide are crucial for implantation in mice. Reproduction, Fertility, and Development 11 183-188. (https://doi.org/10.1071/RD99044)

Pamuklar Z, Lee JS, Cheng HY, Panchatcharam M, Steinhubl S, Morris AJ, Charnigo R \& Smyth SS 2008 Individual heterogeneity in platelet response to lysophosphatidic acid: evidence for a novel inhibitory pathway. Arteriosclerosis, Thrombosis, and Vascular Biology 28 555-561. (https://doi.org/10.1161/ATVBAHA.107.151837)

Panchatcharam M, Miriyala S, Yang F, Rojas M, End C, Vallant C, Dong A, Lynch K, Chun J, Morris AJ et al. 2008 Lysophosphatidic acid receptors 1 and 2 play roles in regulation of vascular injury responses but not blood pressure. Circulation Research 103 662-670. (https://doi.org/10.1161/ CIRCRESAHA.108.180778)

Panchatcharam M, Salous AK, Brandon J, Miriyala S, Wheeler J, Patil P, Sunkara M, Morris AJ, Escalante-Alcalde D \& Smyth SS 2014 Mice with targeted inactivation of ppap $2 b$ in endothelial and hematopoietic cells display enhanced vascular inflammation and permeability. Arteriosclerosis, Thrombosis, and Vascular Biology 34 837-845. (https:// doi.org/10.1161/ATVBAHA.113.302335)

Parfenova H, Parfenov VN, Shlopov BV, Levine V, Falkos S, Pourcyrous M \& Leffler CW 2001 Dynamics of nuclear localization sites for COX-2 in vascular endothelial cells. American Journal of Physiology: Cell Physiology 281 C166-C178. (https://doi.org/10.1152/ajpcell.2001.281.1.C166)

Patrizio P \& Silber S 2017 Improving IVF: is there a limit to our ability to manipulate human biology? Journal of Assisted Reproduction and Genetics 34 7-9. (https://doi.org/10.1007/s10815-016-0828-8)

Pijnenborg R, Dixon G, Robertson WB \& Brosens I 1980 Trophoblastic invasion of human decidua from 8 to 18 weeks of pregnancy. Placenta 1 3-19. (https://doi.org/10.1016/S0143-4004(80)80012-9)

Pijnenborg R, Vercruysse L \& Hanssens M 2006 The uterine spiral arteries in human pregnancy: facts and controversies. Placenta 27 939-958. (https://doi.org/10.1016/j.placenta.2005.12.006)

Plaisier M, Dennert I, Rost E, Koolwijk P, van Hinsbergh VW \& Helmerhorst FM 2009 Decidual vascularization and the expression of angiogenic growth factors and proteases in first trimester spontaneous abortions. Human Reproduction 24 185-197. (https://doi.org/10.1093/ humrep/den296)

Purcell TL, Given R, Chwalisz K \& Garfield RE 1999 Nitric oxide synthase distribution during implantation in the mouse. Molecular Human Reproduction 5 467-475. (https://doi.org/10.1093/molehr/5.5.467)

Ramathal CY, Bagchi IC, Taylor RN \& Bagchi MK 2010 Endometrial decidualization: of mice and men. Seminars in Reproductive Medicine 28 17-26. (https://doi.org/10.1055/s-0029-1242989)

Sano T, Baker D, Virag T, Wada A, Yatomi Y, Kobayashi T, Igarashi Y \& Tigyi G 2002 Multiple mechanisms linked to platelet activation result in lysophosphatidic acid and sphingosine-1-phosphate generation in blood. Journal of Biological Chemistry 277 21197-21206. (https://doi. org/10.1074/jbc.M201289200)

Seo H, Kim M, Choi Y, Lee CK \& Ka H 2008 Analysis of lysophosphatidic acid (LPA) receptor and LPA-induced endometrial prostaglandinendoperoxide synthase 2 expression in the porcine uterus. Endocrinology 149 6166-6175. (https://doi.org/10.1210/en.2008-0354)

Seo H, Choi Y, Shim J, Kim M \& Ka H 2012 Analysis of the lysophosphatidic acid-generating enzyme ENPP2 in the uterus during pregnancy in pigs. Biology of Reproduction 87 77. (https://doi.org/10.1095/ biolreprod.112.099564)

Sharkey AM, Day K, McPherson A, Malik S, Licence D, Smith SK \& Charnock Jones DS 2000 Vascular endothelial growth factor expression in humane endometrium is regulated by hypoxia. Journal of Clinical Endocrinology and Metabolism 85 402-409. (https://doi.org/10.1210/ jcem.85.1.6229)

Sookvanichsilp N \& Pulbutr P 2002 Anti-implantation effects of indomethacin and celecoxib in rats. Contraception $65373-378$. (https:// doi.org/10.1016/S0010-7824(01)00322-5)

Sordelli MS, Beltrame JS, Burdet J, Zotta E, Pardo R, Cella M, Franchi AM \& Ribeiro ML 2011 The effect of anandamide on uterine nitric oxide synthase activity depends on the presence of the blastocyst. PLOS ONE 6 e18368. (https://doi.org/10.1371/journal.pone.0018368)

Sordelli MS, Beltrame JS, Cella M, Gervasi MG, Perez Martinez S, Burdet J, Zotta E, Franchi AM \& Ribeiro ML 2012 Interaction between lysophosphatidic acid, prostaglandins and the endocannabinoid system during the window of implantation in the rat uterus. PLOS ONE 7 e46059. (https://doi.org/10.1371/journal.pone.0046059)

Sordelli MS, Beltrame JS, Zotta E, Gomez N, Dmytrenko G, Sales ME, Blois SM, Davio C, Martinez SP, Franchi AM et al. 2017 Endogenous lysophosphatidic acid participates in vascularisation and decidualisation at the maternal-fetal interface in the rat. Reproduction, Fertility, and Development 29 2112-2126. (https://doi.org/10.1071/RD16235)

Stocco CO \& Deis RP 1998 Participation of intraluteal progesterone and prostaglandin F2 alpha in LH-induced luteolysis in pregnant rat. Journal of Endocrinology 156 253-259. (https://doi.org/10.1677/joe.0.1560253)

Subramanian P, Karshovska E, Reinhard P, Megens RT, Zhou Z, Akhtar S, Schumann U, Li X, van Zandvoort M, Ludin C et al. 2010 Lysophosphatidic acid receptors LPA1 and LPA3 promote CXCL12mediated smooth muscle progenitor cell recruitment in neointima formation. Circulation Research 107 96-105. (https://doi.org/10.1161/ CIRCRESAHA.109.212647)

Sugiura T, Nakane S, Kishimoto S, Waku K, Yoshioka Y \& Tokumura A 2002 Lysophosphatidic acid, a growth factor-like lipid, in the saliva. Journal of Lipid Research 43 2049-2055. (https://doi.org/10.1194/jlr.m200242jlr200)

Sumida H, Noguchi K, Kihara Y, Abe M, Yanagida K, Hamano F, Sato S, Tamaki K, Morishita Y, Kano MR et al. 2010 LPA4 regulates blood and lymphatic vessel formation during mouse embryogenesis. Blood 116 5060-5070. (https://doi.org/10.1182/blood-2010-03-272443)

Tan J, Raja S, Davis MK, Tawfik O, Dey SK \& Das SK 2002 Evidence for coordinated interaction of cyclin D3 with p21 and cdk6 in directing the development of uterine stromal cell decidualization and polyploidy during implantation. Mechanisms of Development 111 99-113. (https:// doi.org/10.1016/S0925-4773(01)00614-1)

Tanaka M, Okudaira S, Kishi Y, Ohkawa R, Iseki S, Ota M, Noji S, Yatomi Y, Aoki J \& Arai H 2006 Autotaxin stabilizes blood vessels and is required for embryonic vasculature by producing lysophosphatidic acid. Journal of Biological Chemistry 281 25822-25830. (https://doi.org/10.1074/jbc. M605142200)

Tigyi G \& Parrill AL 2003 Molecular mechanisms of lysophosphatidic acid action. Progress in Lipid Research 42 498-526. (https://doi.org/10.1016/ S0163-7827(03)00035-3)

Tokumura A 1995 A family of phospholipid autacoids: occurrence, metabolism and bioactions. Progress in Lipid Research 34 151-184. (https://doi.org/10.1016/0163-7827(95)00001-G)

Tokumura A, Fukuzawa K, Akamatsu Y, Yamada S, Suzuki T \& Tsukatani H 1978 a Identification of vasopressor phospholipid in crude soybean lecithin. Lipids 13 468-472. (https://doi.org/10.1007/bf02533615)

Tokumura A, Fukuzawa K \& Tsukatani H $1978 b$ Effects of synthetic and natural lysophosphatidic acids on the arterial blood pressure of different animal species. Lipids 13 572-574. (https://doi.org/10.1007/bf02533598)

Tokumura A, Harada K, Fukuzawa K \& Tsukatani H 1986 Involvement of lysophospholipase $\mathrm{D}$ in the production of lysophosphatidic acid in rat plasma. Biochimica and Biophysica Acta 875 31-38. (https://doi. org/10.1016/0005-2760(86)90007-X)

Tokumura A, Miyake M, Nishioka Y, Yamano S, Aono T \& Fukuzawa K 1999 Production of lysophosphatidic acids by lysophospholipase D in human follicular fluids of in vitro fertilization patients. Biology of Reproduction 61 195-199. (https://doi.org/10.1095/biolreprod61.1.195)

Tokumura A, Kanaya Y, Miyake M, Yamano S, Irahara M \& Fukuzawa K 2002 Increased production of bioactive lysophosphatidic acid by serum lysophospholipase D in human pregnancy. Biology of Reproduction 67 1386-1392. (https://doi.org/10.1095/biolreprod.102.004051)

van Meeteren LA, Ruurs P, Stortelers C, Bouwman P, van Rooijen MA, Pradère JP, Pettit TR, Wakelam MJ, Saulnier-Blache JS, Mummery CL et al. 2006 Autotaxin, a secreted lysophospholipase D, is essential for blood vessel formation during development. Molecular and Cellular Biology 26 5015-5022. (https://doi.org/10.1128/MCB.02419-05)

Vento-Tormo R, Efremova M, Botting RA, Turco MY, Vento-Tormo $M$, Meyer KB, Park JE, Stephenson E, Polański K, Goncalves A et al. 2018 Single-cell reconstruction of the early maternal-fetal interface in humans. Nature 563 347-353. (https://doi.org/10.1038/s41586-018-0698-6) 
Walsh SW \& Coulter S 1989 Increased placental progesterone may cause decreased placental prostacyclin production in preeclampsia. American Journal of Obstetrics and Gynecology 161 1586-1592. (https://doi. org/10.1016/0002-9378(89)90931-9)

Wang H \& Dey SK 2006 Roadmap to embryo implantation: clues from mouse models. Nature Reviews: Genetics 7 185-199. (https://doi. org/10.1038/nrg1808)

Wei Q, St Clair JB, Fu T, Stratton P \& Nieman LK 2009 Reduced expression of biomarkers associated with the implantation window in women with endometriosis. Fertility and Sterility 91 1686-1691. (https://doi. org/10.1016/j.fertnstert.2008.02.121)

Weiss G, Huppertz B, Siwetz M, Lang I \& Moser G 2016 Arterial endothelial cytokines guide extravillous trophoblast invasion towards spiral arteries; an in-vitro study with the trophoblast cell line $\mathrm{ACH}-3 \mathrm{P}$ and female nonuterine endothelial cells. Placenta 38 49-56. (https://doi.org/10.1016/j. placenta.2015.12.010)

Wilcox AJ, Weinberg CR, O'Connor JF, Baird DD, Schlatterer JP, Canfield RE, Armstrong EG \& Nisula BC 1988 Incidence of early loss of pregnancy. New England Journal of Medicine 319 189-194. (https://doi. org/10.1056/NEJM198807283190401)

Wilcox AJ, Baird DD \& Weinberg CR 1999 Time of implantation of the conceptus and loss of pregnancy. New England Journal of Medicine 340 1796-1799. (https://doi.org/10.1056/NEJM199906103402304)

Woclawek-Potocka I, Komiyama J, Saulnier-Blache JS, Brzezicka E, Bah MM, Okuda K \& Skarzynski DJ 2009 Lysophosphatic acid modulates prostaglandin secretion in the bovine uterus. Reproduction 137 95-105. (https://doi.org/10.1530/REP-08-0209)

Woclawek-Potocka I, Kowalczyk-Zieba I \& Skarzynski DJ 2010 Lysophosphatidic acid action during early pregnancy in the cow: in vivo and in vitro studies. Journal of Reproduction and Development $\mathbf{5 6}$ 411-420. (https://doi.org/10.1262/jrd.09-205k)

Xu B, Charlton F, Makris A \& Hennessy A 2014 Nitric oxide (NO) reversed TNF-alfa inhibition of trophoblast interaction with endothelial cellular networks. Placenta 35 417-421. (https://doi.org/10.1016/j. placenta.2014.03.009)

Ye X, Hama K, Contos J, Anliker B, Inoue A, Skinner MK, Suzuki H, Amano T, Kennedy G, Arai H et al. 2005 LPA3-mediated lysophosphatidic acid signalling in implantation and embryo spacing. Nature 435 104-108. (https://doi.org/10.1038/nature03505)

Ye X, Herr DR, Diao H, Rivera R \& Chun J 2011 Unique uterine localization and regulation may differentiate LPA3 from other lysophospholipid receptors for its role in embryo implantation. Fertility and Sterility 95 2107.e1-2113.e1. (https://doi.org/10.1016/j.fertnstert.2011.02.024)

Yukiura H, Hama K, Nakanaga K, Tanaka M, Asaoka Y, Okudaira S, Arima N, Inoue A, Hashimoto T, Arai H et al. 2011 Autotaxin regulates vascular development via multiple lysophosphatidic acid (LPA) receptors in zebrafish. Journal of Biological Chemistry 286 43972-43983. (https:// doi.org/10.1074/jbc.M111.301093)

Yukiura H, Kano K, Kise R, Inoue A \& Aoki J 2015 Autotaxin overexpression causes embryonic lethality and vascular defects. PLOS ONE $\mathbf{1 0}$ e0126734. (https://doi.org/10.1371/journal.pone.0126734)

Yung YC, Stoddard NC \& Chun J 2014 LPA receptor signaling: pharmacology, physiology, and pathophysiology. Journal of Lipid Research 55 1192-1214. (https://doi.org/10.1194/jlr.R046458)

Zhang S, Lin H, Kong S, Wang S, Wang H, Wang H \& Armant DR 2013 Physiological and molecular determinants of embryo implantation. Molecular Aspects of Medicine 34 939-980. (https://doi.org/10.1016/j. mam.2012.12.011)

Zhao L, Wu Y, Xu Z, Wang H, Zhao Z, Li Y, Yang P \& Wei X 2012 Involvement of COX-2/PGE2 signalling in hypoxiainduced angiogenic response in endothelialcells. Journal of Cellular and Molecular Medicine 16 1840-1855. (https://doi.org/10.1111/j.1582-4934.2011.01479.x)

Zhou Y, Fisher SJ, Janatpour M, Genbacev O, Dejana E, Wheelock M \& Damsky CH 1997a Human cytotrophoblasts adopt a vascular phenotype as they differentiate. A strategy for successful endovascular invasion? Journal of Clinical Investigation 99 2139-2151. (https://doi.org/10.1172/ JCl119387)

Zhou Y, Damsky CH \& Fisher SJ 1997b Preeclampsia is associated with failure of human cytotrophoblasts to mimic a vascular adhesion phenotype. One cause of defective endovascular invasion in this syndrome? Journal of Clinical Investigation 99 2152-2164. (https://doi. org/10.1172/JCI119388)

Zhou Z, Subramanian P, Sevilmis G, Globke B, Soehnlein O, Karshovska E, Megens R, Heyll K, Chun J, Saulnier-Blache JS et al. 2011 Lipoproteinderived lysophosphatidic acid promotes atherosclerosis by releasing CXCL1 from the endothelium. Cell Metabolism 13 592-600. (https://doi. org/10.1016/j.cmet.2011.02.016)

Zinaman MJ, Clegg ED, Brown CC, O'connor J \& Selevan SG 1996 Estimates of human fertility and pregnancy loss. Fertility and Sterility $\mathbf{6 5}$ 503-509. (https://doi.org/10.1016/S0015-0282(16)58144-8)

Received 2 November 2018

First decision 6 December 2018

Revised manuscript received 28 July 2019

Accepted 19 August 2019 